\title{
Non-pharmacological strategies to decrease anxiety in cardiac catheterization: integrative review
}

\author{
Estratégias não farmacológicas para diminuição da ansiedade no cateterismo cardíaco: revisão integrativa \\ Estrategias no farmacológicas para disminuir la ansiedad en el cateterismo cardíaco: revisión integradora
}

\author{
Natany da Costa Ferreira', Ercília da Silva Ramalho', Juliana de Lima Lopes" \\ ' Universidade de São Paulo, Clinical Hospital, Heart Institute. São Paulo, Brazil. \\ "Universidade Federal de São Paulo, Department of Nursing. São Paulo, Brazil.
}

How to cite this article:

Ferreira NC, Ramalho ES, Lopes JL. Non-pharmacological strategies to decrease anxiety in cardiac catheterization: integrative review. Rev Bras Enferm. 2015;68(6):784-93. DOI: http://dx.doi.org/10.1590/0034-7167.2015680614i

Submission: 01-08-2015 Approval: 06-10-2015

\begin{abstract}
Objective: to identify and review the literature on non-pharmacological strategies used for reducing anxiety in patients receiving cardiac catheterization. Method: this study was an integrative literature review. The research was conducted using the databases LILACS, SciELO, Medline (through BVS and PubMed) and Scopus. Studies were analyzed according to their objective, method, instruments used for evaluating patients' anxiety, and the results obtained. Results: the most used strategy for reducing anxiety in patients receiving cardiac catheterization was music therapy. However, no study identifying the most appropriate time for this intervention (before, during and/or after the procedure) was found. Other strategies identified in this review were educational videos, massage, and palm therapy. Conclusion: the results found suggest that anxiety can be reduced using non-pharmacological strategies. Keywords: Anxiety; Nursing; Cardiac Catheterization.
\end{abstract}

\section{RESUMO}

Objetivo: identificar na literatura estudos que abordam as estratégias não farmacológicas utilizadas para redução da ansiedade de pacientes que se submetem ao cateterismo cardíaco. Método: trata-se de uma revisão integrativa da literatura, realizada nas bases de dados LILACS, SciELO, Medline (via BVS e PubMed) e Scopus. Os estudos foram analisados de acordo com seu objetivo, métodos, instrumentos utilizados para avaliar ansiedade dos pacientes e resultados obtidos. Resultados: a musicoterapia foi a estratégia mais abordada para a redução da ansiedade. Entretanto, não foi encontrado nenhum estudo que identificasse o momento mais adequado para esta intervenção (antes, durante e/ou após o procedimento hemodinâmico). Outras estratégias identificadas nesta revisão foram o vídeo educacional, massagem e terapia na palma das mãos. Conclusão: os resultados encontrados sugerem que a ansiedade pode ser diminuída com o emprego de estratégias não farmacológicas.

Descritores: Ansiedade; Enfermagem; Cateterismo Cardíaco.

\section{RESUMEN}

Objetivo: identificar y revisar los estudios de literatura que abordan las estrategias no farmacológicas utilizadas para reducir la ansiedad en los pacientes que reciben un cateterismo cardíaco. Método: revisión integradora. La investigación se llevó a cabo utilizando las bases de datos LILACS, SciELO, Medline (BVS y PubMed) y Scopus. Los estudios se analizaron de acuerdo con sus objetivos, la metodo, los instrumentos utilizados para la evaluación de la ansiedad de los pacientes, y los resultados obtenidos. Resultados: la estrategia dirigida más para reducir la ansiedad en los pacientes que recibieron cateterización cardíaca fue la musicoterapia. No se encontró estudio, sin embargo, identificando el momento más adecuado para esta intervención (antes, durante y / o después de este procedimiento). Otras estrategias identificados en esta revisión eran videos educativos, masajes y terapia de palma. Conclusión: los resultados sugieren que la ansiedad se puede reducir el uso de estrategias no farmacológicas. Palabras clave: Ansiedad; Enfermería; Cateterismo Cardíaco.

\section{CORRESPONDING AUTHOR Natany da Costa Ferreira E-mail: natany.ferreira@usp.br}




\section{INTRODUCTION}

Cardiovascular diseases are the main causes of morbidity and mortality worldwide. According to the American Heart Association (AHA), more than 2,150 Americans die of cardiovascular diseases each day, an average of one death every 40 seconds $^{(1)}$. Projections suggest that by 2030, 40.8\% of the American population will have some cardiovascular disease ${ }^{(1)}$.

In patients with ischemic heart disease, acute coronary syndrome is the most dramatic and frightening condition. The treatment for ischemic heart disease can be clinical (by using drugs), surgical (consisting of myocardial revascularization when cardiac catheterization indicates severe obstructive lesions) or vascular (angioplasty), depending on the patient's clinical situation and the degree of coronary artery obstruction ${ }^{(2)}$. Vascular procedures consist of percutaneous coronary intervention, and the method of accessing the heart and the coronary arteries is cardiac catheterization, which can be classified as primary (performed under emergency circumstances) and elective (performed without emergency circumstances) ${ }^{(3)}$. Coronary patients undergoing cardiac catheterization experience several unpleasant feelings, including anxiety, fear, discomfort and distress, anxiety being one of the most common ${ }^{(4-5)}$.

Anxiety is characterized by symptoms such as palpitations, sweating, trembling or shaking, shortness of breath or smothering sensations, chest pain or discomfort, and/or stomach distress ${ }^{(6)}$. Anxiety activates the sympathetic nervous system leading to a variety of physiological responses ${ }^{(7)}$, such as tachycardia, sweating, increased oxygen consumption, hypertension, which can worsen the evolution of the patient. In addition, anxiety can have a negative effect on a patient's clinical outcomes such as treatment refusal and reduced tolerance to pain before, during and after the catheterization intervention. Nurses should implement effective non-pharmacological strategies in order to control patients' anxiety.

In this context, identifying non-pharmacological strategies to reduce anxiety in patients undergoing cardiac catheterization is very important to improve nursing care and to prevent the negative effects of anxiety on patients' clinical outcomes, such as tachycardia and chest pain. To our knowledge, no literature reviews to date have identified non-pharmacological strategies to reduce anxiety in this patient population despite the need for this type of research.

The objective of this review was to identify studies in the published literature about non-pharmacological strategies to reduce anxiety in patients who underwent cardiac catheterization.

\section{METHOD}

An integrative literature ${ }^{(8-9)}$ review was performed in the databases LILACS, SciELO, Medline (through BVS and PubMed) and Scopus. The controlled descriptors used for article search in the databases included "anxiety" and "cardiac catheterization" or "catheterization", and the keyword "apprehension". Inclusion criteria for article selection were studies published from 2002 to 2014, in Portuguese, English or Spanish.

Titles and abstracts were concurrently read and analyzed independently by two researchers, who compared and selected studies to be included. Studies that met all the inclusion criteria were fully read by both researchers. In addition, we included studies in the review that were cited by the articles originally selected but not identified in the databases when the controlled descriptors were used. The authors of the articles that could not be obtained in full through the databases were contacted electronically (Figure 1).

Data from the selected articles were extracted by three researchers using an instrument validated by Ursi ${ }^{(10)}$, ensuring that all relevant data were extracted. The instrument includes

\section{Database and number of articles identified:}

- LILACS: 5 (anxiety AND cardiac catheterization: 3 articles; anxiety AND catheterization: 1 article; apprehension AND cardiac catheterization: 1 article);

- SciELO: 5 (anxiety AND cardiac catheterization: 3 articles; anxiety AND catheterization: 1 article; apprehension AND cardiac catheterization: 1 article);

- PubMed: 277 (anxiety AND cardiac catheterization: 157 articles; anxiety AND catheterization: 102 articles; apprehension AND cardiac catheterization article: 18 articles);

- Scopus: 59 (anxiety AND cardiac catheterization: 33 articles; anxiety AND catheterization: 17 articles; apprehension AND cardiac catheterization: 9 articles).

Total: 346

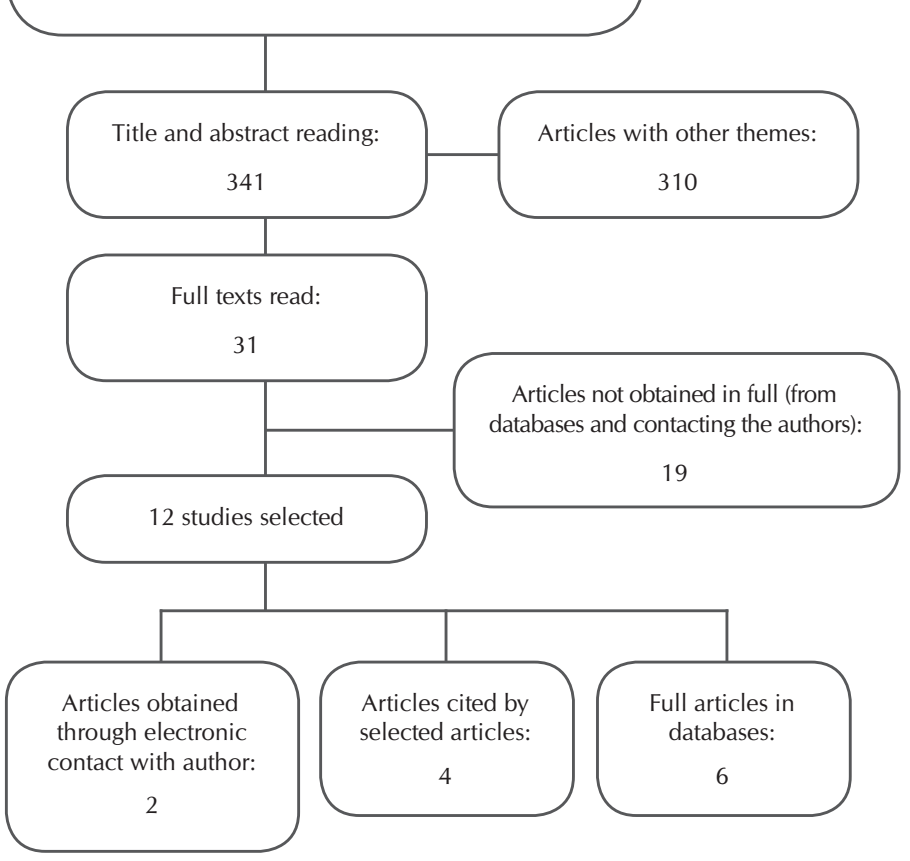

Figure 1 - Article retrieval and selection, São Paulo, Brazil, 2015 
identification of article, journal, authors, country, language, year of publication, institution where the study is based, type of publication, objective or research question, sample, data analysis, interventions, results, analysis, implications, level of evidence and limitations of the study.

The methodological quality of the articles was evaluated through the Jadad scale. This is an instrument with 3 items (randomization, blinding and an account of all patients), totaling 5 points, with a minimum possible score of $2^{(11)}$. Studies with more than 3 points were considered of good quality.

\section{RESULTS}

The twelve selected studies were all clinical trials (two nonrandomized) and published in English ${ }^{(12-23)}$, in $2012(\mathrm{n}=1)$, $2011(n=2), 2009(n=3), 2008(n=1), 2006(n=1), 2004$ $(n=1), 2003(n=2)$, and $2002(n=1)$. The continent where most of them were developed was Asia (5 studies, from Iran, Israel, China, Taiwan and Japan), followed by North America with 4 studies (2 from the USA and 2 from Canada), while 2 studies were developed in Germany and 1 in Australia. In addition, all cardiac catheterizations were elective procedures. The non-randomized clinical trials used music ${ }^{(12)}$ and educational videotapes ${ }^{(13)}$ as strategies to reduce patients' anxiety. Lee et al. ${ }^{(12)}$ randomized patients based on the day of the procedure (patients submitted to the procedure on Wednesdays were assigned to the control group and patients submitted to the procedure on Thursdays were assigned to the intervention group). Chair et al. ${ }^{(13)}$ randomized patients into two groups based on the presence of patients at the pre-admission educational assessment session (patients who were present at the pre-admission assessment session were allocated to the experimental group, whereas the remaining patients were allocated to the control group).

Box 1 shows that the instruments most frequently used to assess patients' anxiety were Spielberger's State-Trait Anxiety Inventory $(n=9)$, the Visual Analogy Scale $(n=3)$, the Numerical Value Scale $(n=2)$ and the Depression, Anxiety and Stress Scale (DASS-21) $(n=1)$; three of the studies reviewed used two distinct scales to assess patients' anxiety ${ }^{(14-16)}$.

Box 1 - Distribution of the selected studies by objectives, intervention, number of participants, instrument, the moment when anxiety was assessed, main results and Jadad scale (quality of reports of randomized clinical trials), São Paulo, Brazil, 2015

\begin{tabular}{|c|c|c|c|c|}
\hline Aims / Jadad Scale & Intervention & $\begin{array}{c}\text { Number of participants/ } \\
\text { Mean age (years) and } \\
\text { gender }\end{array}$ & $\begin{array}{l}\text { Assessment tools/ Time } \\
\text { points }\end{array}$ & Main results \\
\hline $\begin{array}{l}\text { To identify the } \\
\text { effect of music on } \\
\text { anxiety levels in } \\
\text { Chinese patients } \\
\text { before cardiac } \\
\text { catheterization }^{(12)} \text {. } \\
\text { Jadad Scale: } 0\end{array}$ & $\begin{array}{l}\text { Intervention group: music } \\
\text { therapy according to the } \\
\text { patient's preference (sounds } \\
\text { related to the East European/ } \\
\text { Western style and popular } \\
\text { Chinese music), with a duration } \\
\text { of } 20 \text { to } 40 \text { minutes, in a } \\
\text { reclining chair before cardiac } \\
\text { catheterization. In addition } \\
\text { to music therapy, patients } \\
\text { received routine pre-procedure } \\
\text { information such as guidance } \\
\text { about cardiac catheterization. } \\
\text { Control group: routine pre- } \\
\text { procedure information such } \\
\text { as guidance about the cardiac } \\
\text { catheterization, after which the } \\
\text { patients performed relaxation } \\
\text { activities for } 20 \text { to } 40 \text { minutes, } \\
\text { such as reading or watching } \\
\text { television in a waiting room. }\end{array}$ & $\begin{array}{l}\text { Total sample: } 113 \\
\text { Intervention group: } 58 \\
\text { Mean age: } 50.0 \\
\text { Gender: } 27 \text { females } \\
\text { Control group: } 55 \\
\text { Mean age: } 51.9 \\
\text { Gender: } 28 \text { females }\end{array}$ & $\begin{array}{l}\text { Instruments: anxiety: } \\
\text { State-Trait Anxiety } \\
\text { Inventory; blood pressure, } \\
\text { heart rate and respiratory } \\
\text { rate: instrument that } \\
\text { assesses vital signs. } \\
\text { Time points: anxiety: on } \\
\text { the day of the procedure, } \\
\text { after the patient's arrival, } \\
\text { and } 10 \text { minutes after } \\
\text { the intervention; vital } \\
\text { signs: on the day of the } \\
\text { procedure, after the } \\
\text { patient's arrival, and } \\
10 \text { minutes after the } \\
\text { intervention. }\end{array}$ & $\begin{array}{l}\text { All the participants chose } \\
\text { popular Chinese music. In } \\
\text { the first evaluation, the vital } \\
\text { signs and level of anxiety of } \\
\text { the two groups were similar. } \\
\text { There was significant reduction } \\
\text { in the level of anxiety in the } \\
\text { intervention group, compared } \\
\text { with the control group ( } 42.5 \\
\text { versus } 46.4 ; \mathrm{p}=0.005) \text {. } \\
\text { Upon analyzing each group } \\
\text { individually, it was observed } \\
\text { that the control group patients } \\
\text { had their diastolic blood } \\
\text { pressure }(74.0 \text { versus } 72.0 ; \\
\mathrm{p}=0.030), \text { heart rate }(74.1 \\
\text { versus } 70.1 ; \mathrm{p}<0.01) \text { and } \\
\text { respiratory frequency }(17.6 \\
\text { versus } 16.7 ; \mathrm{p}<0.01) \text { reduced } \\
\text { from the first to the second } \\
\text { evaluation. In the intervention } \\
\text { group, there was a reduction } \\
\text { in systolic blood pressure } \\
(127.7 \text { versus } 124.2 ; \mathrm{p}<0.01) \text {, } \\
\text { heart rate ( } 74.3 \text { versus } 71.1 ; \\
\mathrm{p}<0.01), \text { respiratory frequency } \\
(17.7 \text { versus } 16.6 ; \mathrm{p}<0.01) \text { and } \\
\text { anxiety states }(46.1 \text { versus } 42.5 ; \\
\mathrm{p}=0.040) \text {; }\end{array}$ \\
\hline
\end{tabular}




\begin{tabular}{|c|c|c|c|c|}
\hline Aims / Jadad Scale & Intervention & $\begin{array}{l}\text { Number of participants/ } \\
\text { Mean age (years) and } \\
\text { gender }\end{array}$ & $\begin{array}{l}\text { Assessment tools/ Time } \\
\text { points }\end{array}$ & Main results \\
\hline $\begin{array}{l}\text { To examine whether } \\
\text { exposure to music } \\
\text { therapy and } \\
\text { psychoeducational } \\
\text { training reduce } \\
\text { objective and } \\
\text { subjective } \\
\text { anxiety, leading } \\
\text { to a reduction } \\
\text { in anxiolytic } \\
\text { medication }^{(15)} \text {. } \\
\text { Jadad Scale: } 3\end{array}$ & $\begin{array}{l}\text { Intervention group (exposed } \\
\text { to music therapy): patients } \\
\text { listened to a pre-selected song } \\
\text { through earphones immediately } \\
\text { after being placed on the } \\
\text { catheterization table and until } \\
\text { they left the room where the } \\
\text { procedure was performed. } \\
\text { Intervention group (training } \\
\text { group): patients received music } \\
\text { therapy the day before the } \\
\text { cardiac catheterization and } \\
\text { during the procedure. Psycho- } \\
\text { educational training focused } \\
\text { on cognitive behavior was } \\
\text { performed for } 50 \text { minutes, in } \\
\text { addition to which patients were } \\
\text { given guidance concerning the } \\
\text { procedure and some relaxation } \\
\text { training and stress control } \\
\text { through music therapy. } \\
\text { Observation: music for both } \\
\text { intervention groups was } \\
\text { relaxing. } \\
\text { Control group: patients } \\
\text { received the prescribed } \\
\text { medications but did not } \\
\text { receive any verbal or nonverbal } \\
\text { intervention. }\end{array}$ & $\begin{array}{l}\text { Total sample: } 83 \\
\text { Intervention group } \\
\text { (exposure to music } \\
\text { therapy): } 28 \\
\text { Mean age: } 65.8 \\
\text { Gender: } 12 \text { females } \\
\text { Intervention group } \\
\text { (training group): } 28 \\
\text { Mean age: } 66.2 \\
\text { Gender: } 12 \text { females } \\
\text { Control group: } 27 \\
\text { Mean age: } 67.5 \\
\text { Gender: } 12 \text { females }\end{array}$ & $\begin{array}{l}\text { Instruments: objective } \\
\text { anxiety: State-Trait } \\
\text { Anxiety Inventory; } \\
\text { subjective anxiety: } \\
\text { 10-point Visual Analog } \\
\text { Scale; vital signs: } \\
\text { instruments that assess } \\
\text { vital signs. } \\
\text { Time points: objective } \\
\text { and subjective anxiety: } \\
\text { before and after the } \\
\text { procedure; heart rate and } \\
\text { blood pressure: baseline, } \\
\text { before arrival at the unit } \\
\text { and after the procedure. }\end{array}$ & $\begin{array}{l}\text { Music therapy was effective } \\
\text { in reducing subjective } \\
\text { anxiety ( } 11.0 \text { versus } 4.0 \\
\text { versus } 6.0 ; \mathrm{p}=0.033) \text { in both } \\
\text { intervention groups when } \\
\text { compared to the control } \\
\text { group. The hypothesis that } \\
\text { the training group would } \\
\text { further reduce its anxiety } \\
\text { levels in comparison with } \\
\text { the other intervention group } \\
\text { was rejected. Regarding the } \\
\text { use of medications and the } \\
\text { physiological variables, it was } \\
\text { ascertained that there was } \\
\text { no difference between the } \\
\text { groups. }\end{array}$ \\
\hline $\begin{array}{l}\text { To investigate the } \\
\text { effects of music on } \\
\text { patients' anxiety, } \\
\text { angina, pain, } \\
\text { relaxation and } \\
\text { comfort during } \\
\text { angiographic } \\
\text { procedures and } \\
\text { to evaluate the } \\
\text { differences between } \\
\text { genders }{ }^{(16)} \text {. } \\
\text { Jadad Scale: } 3\end{array}$ & $\begin{array}{l}\text { Intervention group: calm } \\
\text { and relaxing music, with } \\
\text { different melodies and } 60 \text { to } \\
80 \text { beats per minute. Music } \\
\text { was played from the moment } \\
\text { the patient was placed on the } \\
\text { catheterization table until he or } \\
\text { she left the unit. The volume } \\
\text { was controlled according } \\
\text { to patient's preference and } \\
\text { was not enough to disturb } \\
\text { communication with the team. } \\
\text { Control group: routine care for } \\
\text { patients submitted to cardiac } \\
\text { catheterization. } \\
\text { Observation: both groups were } \\
\text { divided by gender (male and } \\
\text { female). }\end{array}$ & $\begin{array}{l}\text { Total sample: } 238 \\
\text { Intervention group: } 121 \\
\text { Mean age: } 67.0 \\
\text { Gender: } 60 \text { females } \\
\text { Control group: } 117 \\
\text { Mean age: } 64.0 \\
\text { Gender: } 59 \text { females }\end{array}$ & $\begin{array}{l}\text { Instruments: anxiety } \\
\text { before the procedure, } \\
\text { pain, discomfort from } \\
\text { lying down, easy music: } \\
0-10 \text { Numerical Value } \\
\text { Scale; anxiety after the } \\
\text { procedure: State- Trait } \\
\text { Anxiety Inventory - short } \\
\text { version). } \\
\text { Time points: anxiety } \\
\text { and pain: before the } \\
\text { procedure; pain, } \\
\text { discomfort lying down, } \\
\text { easy music and anxiety: } \\
\text { after the procedure. }\end{array}$ & $\begin{array}{l}\text { There were no differences } \\
\text { between the control group } \\
\text { and the intervention group } \\
\text { for any of the outcomes } \\
\text { evaluated: anxiety ( } 2.0 \\
\text { versus } 2.0 ; p=0.479) \text {, } \\
\text { angina }(0.0 \text { versus } 0.0 ; \\
p=0.741) \text {, pain ( } 3 \text { versus } \\
3 ; p=0.487) \text {, relaxation ( } 8 \\
\text { versus } 8 ; p=0.218) \text {, comfort } \\
\text { ( } 3 \text { versus } 2 ; p=0.260 \text { ) and } \\
\text { ambient sound (10 versus } \\
10 ; p=0.764) \text {. The female } \\
\text { group was more anxious in } \\
\text { comparison with the male } \\
\text { group ( } 3 \text { versus } 1 ; p=0.001) \text {. }\end{array}$ \\
\hline
\end{tabular}




\begin{tabular}{|c|c|c|c|c|}
\hline Aims / Jadad Scale & Intervention & $\begin{array}{c}\text { Number of participants/ } \\
\text { Mean age (years) and } \\
\text { gender }\end{array}$ & $\begin{array}{l}\text { Assessment tools/ Time } \\
\text { points }\end{array}$ & Main results \\
\hline $\begin{array}{l}\text { To examine the } \\
\text { effect of music } \\
\text { on the levels of } \\
\text { anxiety, stress } \\
\text { and depression } \\
\text { experienced by } \\
\text { patients undergoing } \\
\text { coronary } \\
\text { angiography }{ }^{(17)} \text {. } \\
\text { Jadad Scale: } 3\end{array}$ & $\begin{array}{l}\text { Intervention group: music } \\
\text { therapy before and after the } \\
\text { procedure. The music lasted for } \\
20 \text { minutes, containing parts } \\
\text { of three distinct songs, with } \\
70 \text { to } 80 \text { beats per minute and } \\
\text { with stable, slow rhythms. The } \\
\text { patients remained seated in } \\
\text { comfortable chairs and were } \\
\text { advised neither to read, nor to } \\
\text { watch television. } \\
\text { Control group: participants } \\
\text { were evaluated before and } \\
\text { after the procedure and } \\
\text { remained seated in comfortable } \\
\text { chairs for } 20 \text { minutes, being } \\
\text { advised neither to answer } \\
\text { the telephone, listen to the } \\
\text { radio nor watch television - } \\
\text { although they were allowed to } \\
\text { read books, newspapers and } \\
\text { magazines. }\end{array}$ & $\begin{array}{l}\text { Total sample: } 74 \\
\text { Intervention group: } 37 \\
\text { Mean age: } 50.6 \\
\text { Gender: } 15 \text { females } \\
\text { Control group: } 37 \\
\text { Mean age: } 50.6 \\
\text { Gender: } 22 \text { females }\end{array}$ & $\begin{array}{l}\text { Instruments: anxiety: } \\
\text { Depression, Anxiety and } \\
\text { Stress Scale - DASS } 21 \text {. } \\
\text { Time points: anxiety: } \\
1 \text { hour and } 30 \text { minutes } \\
\text { before the procedure, } \\
\text { immediately after the } \\
\text { music therapy in the } \\
\text { intervention group, or } \\
\text { after } 20 \text { minutes of rest } \\
\text { in the control group; } \\
\text { immediately after transfer } \\
\text { to the unit and after the } \\
\text { second intervention after } \\
\text { the procedure. }\end{array}$ & $\begin{array}{l}\text { Upon comparing the two } \\
\text { groups, a statistically- } \\
\text { significant difference was } \\
\text { found for anxiety }(0.71 \text { versus } \\
2.70 ; \mathrm{p}=0.006) \text {, stress }(2.30 \\
\text { versus } 5.19 ; \mathrm{p}=0.001) \text { and } \\
\text { depression }(0.84 \text { versus } 2.19 ; \\
0.002) \text {. These variables, in } \\
\text { the intervention group, had } \\
\text { a significant reduction when } \\
\text { compared to the control } \\
\text { group. }\end{array}$ \\
\hline $\begin{array}{l}\text { To evaluate the } \\
\text { effect of music on } \\
\text { psychophysiological } \\
\text { aspects of patients } \\
\text { awaiting cardiac } \\
\text { catheterization }^{(18)} \text {. } \\
\text { Jadad Scale: } 1\end{array}$ & $\begin{array}{l}\text { Intervention group: music } \\
\text { therapy (sedative) for thirty } \\
\text { minutes at rest and lying with } \\
\text { the bed between } 45 \text { and } 60^{\circ} \text {. } \\
\text { The patients chose one of six } \\
\text { songs (piano, harp, orchestra, } \\
\text { jazz, Chinese orchestra, and } \\
\text { synthesizer). Songs ranged } \\
\text { from } 60 \text { to } 80 \text { beats per minute, } \\
\text { the melodies were gentle and } \\
\text { without dramatic changes in } \\
\text { volume or rhythm. } \\
\text { Control group: usual care at } \\
\text { rest for the patients awaiting } \\
\text { cardiac catheterization. }\end{array}$ & $\begin{array}{l}\text { Total sample: } 54 \\
\text { Intervention group: } 27 \\
\text { Mean age: the article } \\
\text { did not provide this } \\
\text { information } \\
\text { Gender: the article } \\
\text { did not provide this } \\
\text { information } \\
\text { Control group: } 27 \\
\text { Mean age: the article } \\
\text { did not provide this } \\
\text { information } \\
\text { Gender: the article } \\
\text { did not provide this } \\
\text { information }\end{array}$ & $\begin{array}{l}\text { Instruments: assessment } \\
\text { of how the patient felt: } \\
\text { 3-point Likert scale; } \\
\text { anxiety: State-Trait } \\
\text { Anxiety Inventory; heart } \\
\text { rate, heart rate variability } \\
\text { and ST segment: System } \\
\text { BIOPA MP } 150^{\circ} \text {; what } \\
\text { they thought about the } \\
\text { music: Visual Analogue } \\
\text { Scale containing a } 10 \mathrm{~cm} \\
\text { horizontal line in which } 0 \\
\text { cm represents "didn't like } \\
\text { it" and } 10 \text { cm represents } \\
\text { "liked it a lot". } \\
\text { Time points: assessment } \\
\text { of how the patient felt: } \\
\text { before intervention; } \\
\text { state anxiety: baseline } \\
\text { and after music therapy; } \\
\text { physiological evaluations: } \\
\text { six, with reviews every } \\
\text { five minutes during the } \\
\text { music in the intervention } \\
\text { group or at rest in the } \\
\text { control group; music } \\
\text { preference: after the } \\
\text { last assessment of } \\
\text { physiological variables. }\end{array}$ & $\begin{array}{l}\text { Anxiety was reduced in both } \\
\text { groups between the first and } \\
\text { second evaluations. This } \\
\text { reduction, however, was } \\
\text { statistically greater in the } \\
\text { intervention group ( } 9.41 \text { versus } \\
4.96 ; p=0.003 \text { ). Regarding } \\
\text { the physiological variables } \\
\text { (heart rate and ST segment), } \\
\text { although a reduction was } \\
\text { obtained in their scores, } \\
\text { no significant difference } \\
\text { was observed between the } \\
\text { groups. When each group } \\
\text { was evaluated individually, } \\
\text { however, significant differences } \\
\text { were observed between the } \\
\text { first and the second evaluation } \\
\text { in both groups ( } p<0.001 \text { ). } \\
\text { Regarding the variability } \\
\text { of heart rate, there was no } \\
\text { significant difference in any } \\
\text { of the evaluations between } \\
\text { the groups. Regarding } \\
\text { musical preference, piano } \\
\text { music was most commonly } \\
\text { chosen. There was no } \\
\text { correlation between musical } \\
\text { preferences and alterations } \\
\text { in the scores of physiological } \\
\text { variables. However, there } \\
\text { was a significant difference in } \\
\text { musical preference and anxiety } \\
\text { ( } p=0.05 \text { ), indicating that the } \\
\text { greater the patients' satisfaction } \\
\text { in choosing the music type, the } \\
\text { lower their anxiety. }\end{array}$ \\
\hline
\end{tabular}




\begin{tabular}{|c|c|c|c|c|}
\hline Aims / Jadad Scale & Intervention & $\begin{array}{c}\text { Number of participants/ } \\
\text { Mean age (years) and } \\
\text { gender }\end{array}$ & $\begin{array}{l}\text { Assessment tools/ Time } \\
\text { points }\end{array}$ & Main results \\
\hline $\begin{array}{l}\text { To assess the } \\
\text { anxiolytic effects } \\
\text { of different music } \\
\text { styles in patients } \\
\text { submitted to cardiac } \\
\text { catheterization }^{(19)} \text {. } \\
\text { Jadad Scale: } 2\end{array}$ & $\begin{array}{l}\text { Intervention group: patients } \\
\text { who chose one of the following } \\
\text { options during the procedure: } \\
\text { classical music (35), modern } \\
\text { relaxing music (42), jazz (23), no } \\
\text { music (0). } \\
\text { Control group: patients who } \\
\text { were allocated, without choosing } \\
\text { the type of music, in one of the } \\
\text { following options, during the } \\
\text { procedure: classical music (25), } \\
\text { modern relaxing music (25), jazz } \\
\text { (25), no music (25). } \\
\text { Observation: all music had } \\
60 \text { to } 80 \text { beats per minute, a } \\
\text { regular rhythm, and the volume } \\
\text { was adjusted according to the } \\
\text { permitted limit. }\end{array}$ & $\begin{array}{l}\text { Total sample: } 200 \\
\text { Intervention group: } 100 \\
\text { Mean age: the article } \\
\text { did not provide this } \\
\text { information } \\
\text { Gender: } 27 \text { females } \\
\text { Control group: } 100 \\
\text { Mean age: the article } \\
\text { did not provide this } \\
\text { information } \\
\text { Gender: } 36 \text { females }\end{array}$ & $\begin{array}{l}\text { Instruments: anxiety: State- } \\
\text { Trait Anxiety Inventory; } \\
\text { music perception: } \\
\text { questionnaire on music } \\
\text { perception, with scores } \\
\text { ranging from } 10 \text { to } 40 \\
\text { points; blood pressure and } \\
\text { heart rate: questionnaire } \\
\text { assessing vital signs. } \\
\text { Time points: Trait } \\
\text { anxiety: a day before the } \\
\text { procedure; state anxiety: } \\
\text { immediately before and } \\
\text { immediately after the } \\
\text { procedure; questionnaire } \\
\text { on music perception: } \\
\text { after the procedure; } \\
\text { assessment of vital signs: } 7 \\
\text { a.m.; five minutes before } \\
\text { the procedure and five } \\
\text { minutes after cardiac } \\
\text { catheterization. }\end{array}$ & $\begin{array}{l}\text { In the intervention group, } \\
\text { modern relaxing music was } \\
\text { the most effective for anxiety } \\
\text { reduction compared to other } \\
\text { music styles, and in the control } \\
\text { group, classical music and } \\
\text { jazz were the most effective. } \\
\text { Patients who listened to a } \\
\text { specific type of music had a } \\
\text { statistically significant anxiety } \\
\text { reduction when compared to } \\
\text { the group that did not undergo } \\
\text { this intervention (14.9 versus } \\
6.2 ; \text { p }<0.0001 \text { ), and patients } \\
\text { who did not choose the type } \\
\text { of music had a significant } \\
\text { reduction in anxiety levels } \\
\text { when compared with the } \\
\text { other group (16.8 versus } 13.3 \text {; } \\
p=0.0176 \text { ). }\end{array}$ \\
\hline $\begin{array}{l}\text { To determine } \\
\text { whether music } \\
\text { therapy and sensory } \\
\text { information are } \\
\text { effective in reducing } \\
\text { anxiety, uncertainty, } \\
\text { heart rate and } \\
\text { breathing, and } \\
\text { whether it improves } \\
\text { mood before cardiac } \\
\text { catheterization }^{(20)} \text {. } \\
\text { Jadad Scale: } 3\end{array}$ & $\begin{array}{l}\text { Intervention group (music } \\
\text { therapy): music using only } \\
\text { instrumental sounds before the } \\
\text { procedure. } \\
\text { Intervention group (sensory } \\
\text { information): audio cassette } \\
\text { containing sensory information, } \\
\text { i.e., the possible sensations during } \\
\text { the procedure related to sight, } \\
\text { hearing, smell, taste and touch. } \\
\text { Control group: routine nursing } \\
\text { care related to the cardiac } \\
\text { catheterization. }\end{array}$ & $\begin{array}{l}\text { Total sample: } 45 \\
\text { Intervention group with } \\
\text { music therapy: } 15 \\
\text { Mean age: } 56.9 \\
\text { Gender: } 3 \text { females } \\
\text { Intervention group with } \\
\text { sensory information: } 15 \\
\text { Mean age: } 52.9 \\
\text { Gender: } 2 \text { females } \\
\text { Control group: } 15 \\
\text { Mean age: } 65.0 \\
\text { Gender: } 9 \text { females }\end{array}$ & $\begin{array}{l}\text { Instruments: anxiety: } \\
\text { State-Trait Anxiety } \\
\text { Inventory; mood: Profile } \\
\text { of Mood States (POMS); } \\
\text { uncertainty in illness: } \\
\text { Mishel's Uncertainty in } \\
\text { Illness Scale. } \\
\text { Time points: anxiety, } \\
\text { mood swings and } \\
\text { uncertainty in illness: } \\
\text { baseline, } 1 \text { hour before } \\
\text { the procedure and } \\
1 \text { hour after cardiac } \\
\text { catheterization. }\end{array}$ & $\begin{array}{l}\text { None of the intervention } \\
\text { groups (music therapy and } \\
\text { sensory information) nor the } \\
\text { control group significantly } \\
\text { reduced anxiety ( } 3.07 \text { versus } \\
0.07 \text { versus } 2.47 \text { ), improved } \\
\text { mood ( } 0.07 \text { versus } 0.80 \text { versus } \\
3.53) \text {, or reduced uncertainty } \\
\text { (2.07 versus } 0.40 \text { versus } \\
1.20) \text {; furthermore, there was } \\
\text { an increase in cardiac ( } 1.42 \\
\text { versus } 4.20 \text { versus } 2.0 \text { ) and } \\
\text { respiratory frequency }(0.74 \\
\text { versus } 0.20 \text { versus } 0.2) \text {. }\end{array}$ \\
\hline $\begin{array}{l}\text { To determine the } \\
\text { effect of music } \\
\text { on controlled } \\
\text { psychophysiological } \\
\text { stress response } \\
\text { to cardiac } \\
\text { catheterization }^{(21)} \text {. } \\
\text { Jadad Scale: } 3\end{array}$ & $\begin{array}{l}\text { Intervention group: in addition } \\
\text { to the same standard care } \\
\text { received by the control group, } \\
\text { patients listened to music } \\
\text { before, during and after the } \\
\text { procedure, using earphones. } \\
\text { The music therapy started } \\
\text { after patients had completed } \\
\text { the questionnaires prior to the } \\
\text { procedure, and they continued } \\
\text { to listen to music (provided } \\
\text { they wanted to) during and after } \\
\text { the catheterization, before the } \\
\text { second evaluation. } \\
\text { Control group: standard care, } \\
\text { including physical assessment } \\
\text { before the procedure, and } \\
\text { guidance about cardiac } \\
\text { catheterization as well as about } \\
\text { the routine administration } \\
\text { of anxiolytic drugs and local } \\
\text { anesthesia doing the procedure. }\end{array}$ & $\begin{array}{l}\text { Total sample: } 107 \\
\text { Intervention group: } 56 \\
\text { Mean age: } 59.0 \\
\text { Gender: } 24 \text { females } \\
\text { Control group: } 51 \\
\text { Mean age: } 58.0 \\
\text { Gender: } 25 \text { females }\end{array}$ & $\begin{array}{l}\text { Instruments: anxiety: } \\
\text { State-Trait Anxiety } \\
\text { Inventory; pain, fatigue } \\
\text { and dyspnea: } 10 \mathrm{~cm} \\
\text { Visual Analogue Scale; } \\
\text { heart rate: external heart } \\
\text { rate monitor; systolic and } \\
\text { diastolic blood pressure: } \\
\text { indirect blood pressure } \\
\text { measurement. } \\
\text { Time points: anxiety } \\
\text { and pain: before and } \\
\text { after the procedure } \\
\text { and after removing the } \\
\text { introducer; apical heart } \\
\text { rate, systolic and diastolic } \\
\text { blood pressure: baseline } \\
\text { (before application } \\
\text { of the questionnaire, } \\
\text { prior to the start of the } \\
\text { procedure), immediately } \\
\text { before inserting the } \\
\text { introducer, after the } \\
\text { procedure and before } \\
\text { removing the patient } \\
\text { from the cactheterization } \\
\text { table, after the procedure } \\
\text { (immediately before } \\
\text { introducer removal). }\end{array}$ & $\begin{array}{l}\text { There was no significant } \\
\text { difference in the levels of } \\
\text { anxiety and pain between the } \\
\text { groups before ( } 40.7 \text { versus } \\
39.0 ; p=0.28 \text {, and } 0.3 \text { versus } \\
0.1 ; p=0.10 \text {, respectively) } \\
\text { and after the procedures } \\
\text { (33.6 versus } 31.5 ; p=0.17 \text {, } \\
\text { and } 0.5 \text { versus } 0.4 ; p=0.23 \text {, } \\
\text { respectively). Anxiety, } \\
\text { however, was reduced after } \\
\text { the procedure in both groups. } \\
\text { Patients showed high levels of } \\
\text { anxiety before the procedure, } \\
\text { reduced to moderate levels } \\
\text { after the catheterization. } \\
\text { Thus, music therapy did not } \\
\text { interfere in patients' levels of } \\
\text { anxiety or pain. In relation to } \\
\text { the physiological variables, } \\
\text { there was an increase in } \\
\text { heart rate and blood pressure } \\
\text { during the procedure. }\end{array}$ \\
\hline
\end{tabular}




\begin{tabular}{|c|c|c|c|c|}
\hline Aims / Jadad Scale & Intervention & $\begin{array}{c}\text { Number of participants/ } \\
\text { Mean age (years) and } \\
\text { gender }\end{array}$ & $\begin{array}{l}\text { Assessment tools/ Time } \\
\text { points }\end{array}$ & Main results \\
\hline $\begin{array}{l}\text { To measure the } \\
\text { effectiveness of an } \\
\text { educational video } \\
\text { on reducing levels } \\
\text { of uncertainty } \\
\text { and anxiety for } \\
\text { Chinese patients } \\
\text { submitted to cardiac } \\
\text { catheterization }{ }^{(13)} \text {. } \\
\text { Jadad Scale: } 1\end{array}$ & $\begin{array}{l}\text { Intervention group: educational } \\
\text { video lasting } 12 \text { minutes, } \\
\text { containing information on the } \\
\text { cardiac catheterization, the } \\
\text { feelings to be expected during the } \\
\text { procedure and coping strategies. } \\
\text { After the video, patients were } \\
\text { asked if they had any doubts. } \\
\text { In total, the intervention lasted } \\
\text { approximately } 20 \text { minutes. In } \\
\text { addition to the intervention } \\
\text { through the video, patients } \\
\text { received the same routine care as } \\
\text { the control group. } \\
\text { Control group: routine care } \\
\text { for patients receiving cardiac } \\
\text { catheterization, including a } \\
\text { pamphlet about the procedure } \\
\text { containing information on } \\
\text { diet, preparation of the skin, } \\
\text { the routine of hemodynamic } \\
\text { observation and pain control. }\end{array}$ & $\begin{array}{l}\text { Total sample: } 128 \\
\text { Intervention group: } 64 \\
\text { Mean age: } 60.5 \\
\text { Gender: } 20 \text { females } \\
\text { Control group: } 64 \\
\text { Mean age: } 62.11 \\
\text { Gender: } 25 \text { females }\end{array}$ & $\begin{array}{l}\text { Instruments: anxiety: } \\
\text { State-Trait Anxiety } \\
\text { Inventory: uncertainty: } \\
\text { Mishel's Uncertainty in } \\
\text { Illness Scale; satisfaction } \\
\text { level and perception } \\
\text { of knowledge about } \\
\text { the procedure: Visual } \\
\text { Analogue Scale. } \\
\text { Time points: anxiety and } \\
\text { uncertainty: baseline } \\
\text { (before video), } 2 \text { hours } \\
\text { before the procedure and } \\
\text { after the intervention; } \\
\text { satisfaction and } \\
\text { perception of knowledge } \\
\text { about the procedure: } \\
\text { from } 20 \text { to } 24 \text { hours after } \\
\text { cardiac catheterization } \\
\text { and before discharge of } \\
\text { the patient. }\end{array}$ & $\begin{array}{l}\text { The use of the educational } \\
\text { video was effective in } \\
\text { reducing levels of anxiety } \\
\text { ( } 4.9 \text { versus } 1.4 ; p<0.001) \\
\text { and uncertainty }(15.2 \text { versus } \\
2.7 ; p<0.001) \text { in patients } \\
\text { who underwent cardiac } \\
\text { catheterization. In addition, } \\
\text { the educational video } \\
\text { increased these patients' } \\
\text { satisfaction and levels of } \\
\text { knowledge in comparison } \\
\text { with the control group. }\end{array}$ \\
\hline $\begin{array}{l}\text { To examine } \\
\text { the effect of a } \\
\text { psychoeducational } \\
\text { nursing intervention } \\
\text { in patients' anxiety } \\
\text { early in the } \\
\text { waiting period for } \\
\text { elective cardiac } \\
\text { catheterization }^{(14)} \text {. } \\
\text { Jadad Scale: } 3\end{array}$ & $\begin{array}{l}\text { Intervention group (nursing } \\
\text { education): nursing education } \\
\text { one hour before cardiac } \\
\text { catheterization, including a } \\
\text { nursing visit, and presentation } \\
\text { of written and visual material. } \\
\text { Control group: these patients } \\
\text { received the unit routine care } \\
\text { for patients who undergo } \\
\text { cardiac catheterization. }\end{array}$ & $\begin{array}{l}\text { Total sample: } 228 \\
\text { Control group: } 114 \\
\text { Mean age: } 62.9 \\
\text { Gender: } 49 \text { females } \\
\text { Intervention group: } 114 \\
\text { Mean age: } 64.7 \\
\text { Gender: } 41 \text { females }\end{array}$ & $\begin{array}{l}\text { Instruments: anxiety: } \\
\text { State-Trait Anxiety } \\
\text { Inventory and 0-10 } \\
\text { Verbal Scale; quality of } \\
\text { life: SF36; disease self- } \\
\text { management functional } \\
\text { status: SAQ. } \\
\text { Time points: baseline } \\
\text { (two weeks before the } \\
\text { cardiac catheterization); } \\
\text { pre-cardiac } \\
\text { catheterization (after the } \\
\text { educational intervention). }\end{array}$ & $\begin{array}{l}\text { Anxiety increased in both } \\
\text { groups over the waiting time } \\
\text { ( } 1.3 \text { versus } 1.6 ; p=0.028) \text {. } \\
\text { Anxiety was significantly higher } \\
\text { in the control group ( } 4.0 \text { versus } \\
5.2 ; p=0.002) \text {. Regarding } \\
\text { quality of life and disease self- } \\
\text { management functional status, } \\
\text { in the first evaluation there } \\
\text { was no significant difference } \\
\text { between the groups. However, } \\
\text { a difference in quality of life } \\
\text { (0.4 versus } 3.2 ; p=0.06) \text { was } \\
\text { observed when the first and } \\
\text { second assessments were } \\
\text { compared. }\end{array}$ \\
\hline $\begin{array}{l}\text { To investigate, } \\
\text { in two studies, if } \\
\text { palm therapy is } \\
\text { effective in reducing } \\
\text { anxiety in patients } \\
\text { submitted to cardiac } \\
\text { catheterization }^{(23)} \text {. } \\
\text { Jadad Scale: } 4\end{array}$ & $\begin{array}{l}\text { First study: } \\
\text { Intervention group: palm } \\
\text { therapy for } 45 \text { minutes and } \\
\text { conversation between the } \\
\text { patient and the therapist during } \\
\text { the session. } \\
\text { Control group: pressure on the } \\
\text { palms of their hands in places } \\
\text { that have no effect. } \\
\text { Second study: } \\
\text { Intervention group: palm } \\
\text { therapy for } 45 \text { minutes and } \\
\text { conversation between the } \\
\text { patient and a second person } \\
\text { during the session. } \\
\text { Control group: pressure on the } \\
\text { palms of the hands in places } \\
\text { that have no effect. }\end{array}$ & $\begin{array}{l}\text { First study: } \\
\text { Total sample: } 23 \\
\text { Control group: } 9 \\
\text { Mean age and gender: } \\
\text { the article did not provide } \\
\text { this information } \\
\text { Intervention group: } 14 \\
\text { Mean age and gender: } \\
\text { the article did not provide } \\
\text { this information } \\
\text { Second study: } \\
\text { Total sample: } 17 \\
\text { Control group: } 10 \\
\text { Mean age and gender: } \\
\text { the article did not provide } \\
\text { this information } \\
\text { Intervention group: } 7 \\
\text { Mean age and gender: } \\
\text { the article did not provide } \\
\text { this information }\end{array}$ & $\begin{array}{l}\text { Instruments: patients' } \\
\text { self-report of anxiety; } \\
\text { patients' and nurses' } \\
\text { perception about patients' } \\
\text { anxiety: Visual Analogue } \\
\text { Scale. } \\
\text { Time points: before and } \\
\text { after treatment. }\end{array}$ & $\begin{array}{l}\text { First study: } \\
\text { Patients of both groups had } \\
\text { similar levels of anxiety } \\
\text { before the intervention. After } \\
\text { the intervention, anxiety was } \\
\text { lower in the patients who had } \\
\text { received palm therapy, both } \\
\text { in relation to self-reported } \\
\text { anxiety ( } 7.1 \text { versus } 40.1 ; \\
p=0.0001) \text { and according } \\
\text { to the nurses' perception of } \\
\text { their anxiety ( } 4.6 \text { versus } 12.6 \text {; } \\
p=0.0001) \text {. } \\
\text { Second study: } \\
\text { Patients of the intervention } \\
\text { group had significantly } \\
\text { lower anxiety in comparison } \\
\text { with the control group, but } \\
\text { only regarding self-reported } \\
\text { anxiety (11.8 versus 30.0; } \\
p=0.005 \text { ). }\end{array}$ \\
\hline
\end{tabular}




\begin{tabular}{|c|c|c|c|c|}
\hline Aims / Jadad Scale & Intervention & $\begin{array}{c}\text { Number of participants/ } \\
\text { Mean age (years) and } \\
\text { gender }\end{array}$ & $\begin{array}{l}\text { Assessment tools/ Time } \\
\text { points }\end{array}$ & Main results \\
\hline $\begin{array}{l}\text { To evaluate the } \\
\text { efficacy of a } \\
\text { 20-minute massage } \\
\text { in the reduction } \\
\text { in patient levels } \\
\text { of pain, anxiety } \\
\text { and stress before } \\
\text { an invasive } \\
\text { cardiovascular } \\
\text { procedure; to } \\
\text { assess patient } \\
\text { satisfaction with the } \\
\text { massage; to assess } \\
\text { the feasibility of } \\
\text { therapeutic massage } \\
\text { practices before the } \\
\text { procedure } \\
\text { Jadad Scale: } 4\end{array}$ & $\begin{array}{l}\text { Intervention group: therapeutic } \\
\text { massage for } 20 \text { minutes. The } \\
\text { patients chose the area (head, } \\
\text { nape, shoulders, arms, hands, } \\
\text { back, legs and feet) and the } \\
\text { strength used in the massage. } \\
\text { Control group: } 20 \text { minutes of } \\
\text { standardized care, lying on } \\
\text { the bed or sitting in the chair, } \\
\text { relaxing, reading a book, } \\
\text { or conversing with family } \\
\text { members or with the nursing } \\
\text { team. }\end{array}$ & $\begin{array}{l}\text { Total sample: } 130 \\
\text { Intervention group: } 64 \\
\text { Mean age: } 67.2 \\
\text { Gender: } 22 \text { females } \\
\text { Control group: } 66 \\
\text { Mean age: } 59.7 \\
\text { Gender: } 22 \text { females }\end{array}$ & $\begin{array}{l}\text { Instruments: anxiety, } \\
\text { pain, muscle tension and } \\
\text { satisfaction: } 10 \text {-point } \\
\text { Visual Analogue Scale. } \\
\text { Time points: anxiety, } \\
\text { pain, muscle tension } \\
\text { and satisfaction: in the } \\
\text { morning (immediately } \\
\text { before the therapeutic } \\
\text { massage), } 2 \text { to } 5 \text { minutes } \\
\text { after the intervention. }\end{array}$ & $\begin{array}{l}\text { In the intervention group, } \\
\text { pain }(-1 \text { versus }-0.1 ; \\
p<0.001) \text {, muscle tension } \\
(-2.1 \text { versus }-0.3 ; p<0.001) \\
\text { and anxiety }(-2.1 \text { versus } 0.0 \text {; } \\
p<0.001) \text { were reduced } \\
\text { more effectively and their } \\
\text { levels of satisfaction were } \\
\text { greater }(p=0.002) \text {. }\end{array}$ \\
\hline
\end{tabular}

The following non-pharmacological strategies were utilized to reduce the anxiety of patients undergoing cardiac catheterization: music therapy $(n=8 ; 66.7 \%)^{(12,15-21)}$, educational videos $(n=2 ; 16.7 \%)^{(13-14)}$, massage $(n=1 ; 8.3 \%)^{(22)}$, palm therapy $(\mathrm{n}=1 ; 8.3 \%)^{(23)}$ and psychoeducational training $(\mathrm{n}=1 ; 8.3 \%)$ ${ }^{(15)}$. One study ${ }^{(15)}$ used two interventions (music therapy and psychoeducational training); however, music was its main intervention. Music therapy was shown to be effective in most of the studies, with p-values ranging from $<0.001$ to 0.033 , as shown in Box $1^{(12,15,17-18)}$. Several studies showed that music therapy reduced anxiety ${ }^{(12,15,17-19)}$, stress, depression ${ }^{(17)}$ and physiological markers of anxiety, such as systolic blood pressure, heart rate and respiratory frequency ${ }^{(13)}$, with statistically significant differences in comparison with control groups, as shown in Box 1. Regarding the moment when the intervention was carried out, some studies performed the interventions before catheterization ${ }^{(12,18,20)}$, others during the procedure ${ }^{(15,18-19)}$, another before and after the hemodynamic procedure ${ }^{(17)}$ and another before, during and after the cardiac catheterization ${ }^{(21)}$. However, no study identified whether before or during the procedure was the most effective for the intervention.

Patients did not choose their preferred music in most of the studies $^{(15-17,20-21)}$. One study demonstrated that patients who did not get to choose the type of music had a significant reduction in anxiety compared to patients able to choose their preferred music $(p=0.0176)^{(19)}$. Generally, the music was relaxing (60 to 80 beats per minute) with no drastic volume or rhythm changes.

In addition to music therapy, other strategies were identified to reduce anxiety in patients undergoing to cardiac catheterization, although there were very few of these. Other interventions discussed in this review include: educational videos, massage, and palm therapy.

Two studies showed that educational videos were effective in reducing anxiety in patients who underwent cardiac catheterization ${ }^{(13-14)}$. This strategy was effective because the videos contained information about the procedure and discussed and anticipated feelings that may arise during the procedure.
It was observed that the strategy of administering a massage for 20 minutes was also effective for anxiety reduction in these patients ${ }^{(22)}$. A study by Blaer et al. ${ }^{(23)}$ showed that anxiety levels were reduced in the group that received palm therapy for 45 minutes. Palm therapy is a moderate continuous pressure on specific points of the palm that are supposed to represent specific areas of the brain and may be effective for reducing some signs and symptoms presented by patients ${ }^{(23)}$.

\section{DISCUSSION}

There is very little evidence in the literature about the effectiveness of non-pharmacological strategies for anxiety reduction in patients undergoing cardiac catheterization. In the majority of the studies identified in this review, non-pharmacological interventions were effective, music therapy being the most commonly used.

Music can help eliminate pain and reduce stress and tension, besides inducing relaxation ${ }^{(24)}$. Music is an ideal non-pharmacological intervention in that it is easily accessible, inexpensive and favors anxiety reduction and physiological activity ${ }^{(25)}$.

Among the studies that used music therapy as an intervention to reduce anxiety and let subjects choose their preferred music, it was observed that the most common music style chosen was classical music. However, from our review, it appeared that choosing the music did not influence patients' level of anxiety. One explanation may be that patients frequently expressed doubt in their decision and worried that health professionals may not like their choice ${ }^{(19)}$, subsequently increasing anxiety levels.

In spite of music being the intervention most frequently used as a strategy for anxiety reduction in patients undergoing cardiac catheterization, there was no consensus about the best type of music, or the best time for listening to it. This consensus may not be established due to the heterogeneity of methods used in the reviewed studies. In this context, future studies should be conducted with consistent methodology. 
Although the other strategies identified in this review (educational video, massage and palm therapy) have shown positive results in reducing anxiety in patients undergoing cardiac catheterization, there are few publications to highlight their clinical benefits. For this reason, further studies are needed to validate these findings.

The use of educational sessions before admission, such as instructions about the procedure through videos, showed effective improvements in the knowledge of hospital procedures and a reduction in patients' anxiety ${ }^{(26)}$. Studies show that patients become calmer when they have the opportunity to know more about the upcoming procedure; nurses can mitigate patient anxiety by offering systematized information about the procedure to the patient ${ }^{(13-14)}$. However, a few studies were performed with the aim of identifying the effectiveness of educational videos to reduce the level of anxiety of patients undergoing cardiac catheterization.

In relation to the study on massage, it was observed that it promotes relaxation, and reduces stress and anxiety ${ }^{(27)}$. The study that used palm therapy was based on the theory that the palm of the hand represents the entire body in miniature and that certain points correspond to specific areas of the brain, both motor and sensory. Hence, moderate continuous pressure on specific points of the palm of the hand can reduce anxiety effectively ${ }^{(23)}$. Studies show that alternative therapies are increasingly being used to reduce patients' anxiety ${ }^{(28-29)}$, and these interventions must be considered by health professionals when dealing with anxious patients.
It is worth emphasizing the methodological quality of the reviewed studies. The majority of studies were considered of good quality. The studies classified as poor did not describe how the authors performed the randomization ${ }^{(18-19)}$, did not explain the account of all patients ${ }^{(12,18)}$ or did not randomize the patients $^{(12-13)}$. The majority of the articles reviewed did not describe the study settings and did not control some aspects that could have changed patients' anxiety, such as the light color ${ }^{(30)}$. Another result that should be emphasized is that, although most of the studies were clinical trials, sample sizes were small, ranging from 17 to 238 participants; some studies did not calculate sample size. Others studies are needed to validate these results. Another limitation is that we did not include all relevant studies due to the exclusion criteria "full text not available".

\section{CONCLUSION}

This review identified strategies used to reduce anxiety in patients submitted to cardiac catheterization, including music therapy, palm therapy, educational videos and massage. These studies suggested that anxiety can be reduced through these four strategies and may be administered by nursing staff. It is known that reducing anxiety can decrease heart rate and blood pressure, thereby reducing oxygen consumption, which may be beneficial for the patient's prognosis. However, because this is an integrative literature review, we did not perform a meta-analysis and future systematic literature reviews should be performed in order to identify the effectiveness of these strategies.

\section{REFERENCES}

1. American Heart Association. Heart Disease and Stroke Statistics: 2013 Update: a report from the American Heart Association. Circulation [Internet]. 2013[cited 2014 Dec 2]; Available from: http://www.circ.ahajournals.org/ content/127/1/e6

2. Nicolau JC, Timerman A, Marin-Neto JA, Piegas LS, Barbosa CJDG, Avezum Júnior A, et al. Guidelines of the Brazilian Society of Cardiology on unstable angina and myocardial acurte infartion without ST-segment elevation (II Edition, 2007) - Atualization 2013/2014. Arq Bras Cardiol [Internet]. 2014[cited 2014 May 30];102(3supl 1):1-75. Available from: http://publicacoes.cardiol.br/consenso/2014/Diretriz de_IAM.pdf

3. Harold JG, Bass TA, Bashore TM, Brindis RG, Brush JE, Burke JA, et al. ACCF/AHA/SCAI 2013 update of the clinical competence statement on coronary artery interventional procedures: a report of the American College of Cardiology Foundation/American Heart Association/American College of Physicians Task Force on Clinical Competence and Training (Writing Committee to Update the 2007 Clinical Competence Statement on Cardiac Interventional Procedures). Circulation [Internet]. 2013[cited 2014 Jul 25]; 8:1-87. Available from: http://circ.ahajournals.org/content/128/4/436

4. Trotter R, Gallagher R, Donoghue J. Anxiety in patients undergoing percutaneous coronary interventions. Heart
Lung [Internet]. 2011[cited 2014 Aug 24];40(3):185-92. Available from: http://www.sciencedirect.com/science/ article/pii/S0147956310002098

5. Munk PS, Isaksen K, Bronnick K, Kurz MW, Butt N, Larsen AI. Symptoms of anxiety and depression after percutaneous coronary intervention are associated with decreased heart rate variability, impaired endothelial function and increased inflammation. Int J Cardiol [Internet]. 2012[cited 2014 May 12]; 58(1):173-6. Available from: http://www.sciencedirect. com/science/article/pii/S0167527312005062

6. American Psichiatric Association. DSM-V. Manual Diagnóstico e Estatístico de Transtornos Mentais. São Paulo: Artmed, 2014.

7. Player MS, Peterson LE. Anxiety disorders, hypertension, and cardiovascular risk: a review. Int J Psychiatry Med [Internet]. 2011[cited 2014 May 12];41(4):365-77. Available from: http://ijp.sagepub.com/content/41/4/365.long

8. Broome ME. Integrative literature reviews in the development of concepts. In: Rodgers BL, Knafl KA. Concept development in nursing: foundations, techniques and applications. Philadelphia: W.B. Saunders; 1993. p.193-215.

9. Ganong $\mathrm{LH}$. Integrative reviews of nursing research. Res Nurs Health 1987;10:1-11.

10. Ursi ES, Gavão MC. Perioperative prevention of skin injury: 
an integrative literature review. Rev Latino-Am Enfermagem [Internet]. 2006 Feb[cited 2015 Jan 23];14(1):124131. Available from: http://www.scielo.br/pdf/rlae/v14n1/ v14n1a17.pdf

11. Jadad AR, Moore RA, Carroll D, Jenkinson C, Reynolds DJ, Gavaghan DJ, et al. Assessing the quality of reports of randomized clinical trials: is blinding necessary? Control Clin Trial. 1996;17(1):1-12.

12. Lee D, Henderson A, Shum D. The effect of music on procedure anxiety in Hong Kong Chinese day patients. J Clin Nurs [Internet]. 2004[cited 2014 May 15];13(3):297303. Available from: http://onlinelibrary.wiley.com/ doi/10.1046/j.1365-2702.2003.00888.x/full

13. Chair SY, Chau MY, Sit JWH, Wong EML, Chan AWK. The psychological effects of a videotape educational intervention on cardiac catheterization patients. Contemp Nurse [Internet]. 2012[cited 2014 May 15];40(2):225-33. Available from: http://www.tandfonline.com/doi/abs/10.5172/ conu.2012.40.2.225

14. Harkness K, Morrow L, Smith K, Kiczula M, Arthur HM. The effect of early education on patient anxiety while waiting for elective cardiac catheterization. Eur J Cardiovasc Nurs. 2003[cited 2015 Jan 25];2(2):113-21. Available from: http://cnu.sagepub.com/content/2/2/113.long

15. Argstatter $\mathrm{H}$, Haberbosch W, Bolay HV. Study of the effectiveness of musical stimulation during intracardiac catheterization. Clin Res Cardiol [Internet]. 2006[cited 2015 Jul 30];95(10):514-22. Available from: http://link.springer. com/article/10.1007\%2Fs00392-006-0425-4

16. Nilsson U, Lindell L, Eriksson A, Kellerth T. The effect of music intervention in relation to gender during coronary angiographic procedures: a randomized clinical trial. Eur J Cardiovasc Nurs [Internet]. 2009[cited 2014 Dec 12];8(3):200-6. Available from http://cnu.sagepub.com/ content/8/3/200.full

17. Moradipanah F, Mohammadi E, Mohammadil AZ. Effect of music on anxiety, stress, and depression levels in patients undergoing coronary angiography. East Mediterr Health J [Internet]. 2009[cited 2015 Jul 30];15(3):639-47. Available from: http://www.ncbi.nlm.nih.gov/pubmed/19731780

18. Hui-Kuan C, Peng TC, Wang JH, Lai HL. Psychophysiological responses to sedative music in patients awaiting cardiac catheterization examination: a randomized controlled trial. J Cardiovasc Nurs [Internet]. 2011[cited 2015 Jul 30];26(5):E11-8. Available from: http://www.ncbi.nlm. nih.gov/pubmed/21372737

19. Goertz W, Dominick K, Heussen N, Dahl JV. Music in the cath lab: who should select it? Clin Res Cardiol [Internet]. 2011[cited 2015 Jul 30];100(5):395-402. Available from: http://link.springer.com/article/10.1007\%2Fs00392-0 10-0256-1

20. Taylor-Piliae RE, Chair SY. The effect of nursing interventions utilizing music therapy or sensory information on Chinese patients ' anxiety prior to cardiac catheterization: a pilot study. Eur J Cardiovasc Nurs [Internet]. 2002[cited 2015 Jul 30];1(3):203-11. Available from: http://cnu.sagepub.com/ content/1/3/203.long

21. Bally K, Campbell D, Chesnick K, Tranmer JE. Effects of patient-controlled music therapy during coronary angiography on procedural pain and anxiety distress syndrome. Crit Care Nurse [Internet]. 2003[cited 2014 Nov 23];23(2):50-8. Available from: http://ccn.aacnjournals.org/ content/23/2/50.full

22. Wentworth LJ, Briese LJ, Timimi FK, Sanvick CL, Bertel DC, Cutshall SM, et al. Massage Therapy reduces tension, anxiety, and pain in patients awaiting invasive cardiovascular procedures. Prog Cardiovasc Nurs [Internet]. 2009[cited 2015 Jul 30];24(4):155-61. Available from: http://onlinelibrary.wiley. com/doi/10.1111/j.1751-7117.2009.00054.x/epdf

23. Blaer Y, Jafari J, Podberezsky A, David T, Reizin L, Benjamin J. Single-blind and double blind randomized controlled trials of palmtherapy, an alternative medical approach, for anxiety before cardiac catheterization. Evid Based Complement Alternat Med [Internet]. 2008[cited 2015 Jul 30];5(1):103-5. Available from: http://www.ncbi. nlm.nih.gov/pmc/articles/PMC2249735/pdf/nel111.pdf

24. Tan X, Yowler CJ, Super DM, Fratianne RB. The efficacy of music therapy protocols for decreasing pain, anxiety, and muscle tension levels during burn dressing changes: a prospective randomized crossover trial. J Burn Care Res [Internet]. 2010[cited 2015 Jul 30];31(4):590-7. Available from: http://www.ncbi.nlm.nih.gov/pubmed/20498613

25. Hamel WJ. The effects of music intervention on anxiety in the patient waiting for cardiac catheterization. Intensive Crit Care Nurs [Internet]. 2001[cited 2015 Jul 30];17(5):27985. Available from: http://www.sciencedirect.com/science/ article/pii/S0964339701915940

26. Stern C, Lockwood C. Knowledge retention from preoperative patient information. Int J Evid Based Healthc [Internet]. 2005[cited 2015 Jul 30];3(3):45-63. Available from: http://www.ncbi.nlm.nih.gov/pubmed/21631744

27. Buttagat V, Eungpinichpong W, Chatchawan U, Kharmwan S. The immediate effects of traditional Thai massage on heart rate variability and stress related parameters in patients with back pain associated with myofascial trigger points. J Bodyw Mov Ther [Internet]. 2011[cited 2015 Jan 2];15(1):15-23. Available from: http://www.sciencedirect. com/science/article/pii/S1360859209000801

28. Ravindran AV, da Silva TL. Complementary and alternatives therapies as add-on to phamarcotherapy for mood and anxiety disorders: a systematic review. J Affect Disord [Internet]. 2013[cited 2014 Nov 13];150(3):707-19. Available from: http://www.sciencedirect.com/science/article/ pii/S0165032713004217

29. Bystritsky A, Hovav S, Sherbourne C, Stein MB, Rose RD, Campbell-Sills L, et al. Use of complementary and alternative medicine in a large sample of anxiety patients. Psychosomatics [Internet]. 2012[cited 2014 Nov 21];53(3):266-72. Available from: http://www.sciencedirect.com/science/ article/pii/S0033318211003598

30. Choi CJ, Kim KS, Kim CM, Kim SH, Choi WS. Reactivity of heart rate variability after exposure to colored lights in healthy adults with symptoms of anxiety and depression. In J Psychophysiol [Internet]. 2011[cited 2014 Dec 2];79(2):83-88. Available from: http://www.sciencedirect. com/science/article/pii/S0167876010007117 